\title{
Identification key for the Brazilian species and subspecies of the family llyocryptidae (Crustacea, Branchiopoda, Anomopoda)
}

\author{
Francisco Diogo Rocha Sousa ${ }^{1,2,3}$ \& Lourdes Maria Abdu Elmoor-Loureiro ${ }^{2,4}$ \\ 1 Universidade Federal de Jataí (UFJ), Unidade Acadêmica Especial de Ciências Biológicas. Jataí, G0, Brasil. \\ ${ }^{2}$ Universidade Católica de Brasília (UCB), Grupo de Estudos de Ecossistemas Aquáticos (GEEA). Brasília, DF, Brasil. \\ ${ }^{3}$ ORCID: http://orcid.org/0000-0003-4389-8140. E-mail: fdiogo.rs@gmail.com (corresponding author) \\ 4 ORCID: http://orcid.org/0000-0001-7439-9753. E-mail: lourdes@ucb.br
}

\begin{abstract}
In recent years, an increase in knowledge about the diversity and biogeography of Brazilian Cladocera fauna has been evident. To keep up with these changes, it is opportune to carry out an update of the taxonomy and biogeography for the main cladoceran groups. Since 2008, some progress has been observed in llyocryptidae, with reports of four new taxa. In this study, an updated checklist of llyocryptidae from Brazil is provided, with a diagnosis for each cited taxon, as well as an identification key. Some of these taxa are considered rare; however, this issue might be an artifact of sampling. As this is the first in a series of papers compiling current information about Brazilian Cladocera, an identification key to orders and families occurring in Brazil is also provided.
\end{abstract}

Key-Words. Cladocera; Ctenopoda; Microcrustaceans; Postabdomen; Setae; Valves.

\section{INTRODUCTION}

Following the pattern of the cladocerans belonging to the Order Anomopoda, the taxonomy of llyocryptidae Smirnov 1976 emend. Smirnov, 1992 has faced several problems and controversies since the description of its first representative, at that time under the name Acanthocercus Liévin, 1848. A little later in the $19^{\text {th }}$ century, its members were transferred to the genus llyocryptus Sars, 1862 (Kotov \& Štifter, 2006), because the morphological bases for the delimitation of Acanthocercus were inappropriate. In the $20^{\text {th }}$ century, a debate arose concerning the position of the genus in more inclusive hierarchical levels and about the possible underestimations of its species diversity, triggered by the publication of a book on the Macrothricidae and Moinidae of the world, written by the renowned cladoceran researcher Nikolai N. Smirnov (Smirnov, 1976). In this study, Smirnov created the subfamily Ilyocryptinae Smirnov, 1976, subordinate to Macrothricidae Norman \& Brady, 1867 emend. Dumont \& SilvaBriano, 1998.

As a result of the increase in the number of described species, combined with an improved knowledge of this group's morphology and ecol- ogy, Smirnov (1992) raised the llyocryptinae to the status of family. Indeed, the llyocryptidae is the best example of a specialized lineage within the Anomopoda, exhibiting both internal and external anatomical adaptations related to its life history traits. Most species of Ilyocryptus spend their lives buried in flocculated organic matter (Fryer, 1974). Only a few species are abundantly found in the highest strata from the bottom of water bodies, or in association with macrophytes, such as the cosmopolitan Ilyocryptus spinifer Herrick 1882.

Even though information on the cladocerans of Brazil is mainly provided by one book (ElmoorLoureiro, 1997), which is the touchstone for the accumulated knowledge of Neotropical cladocerans, specific information leading to the stability of the llyocryptidae in Brazil was only obtained after the revision of the family published by Kotov \& Elmoor-Loureiro (2008). After this publication, new studies reported an increase in the geographical range of some species and the inclusion of new taxa into the Brazilian cladoceran fauna (Sousa et al., 2010; Sousa \& Elmoor-Loureiro, 2011, $2012,2013)$. In this context, it is important to construct an identification key that incorporates all these changes reported for the Brazilian cladocer- 

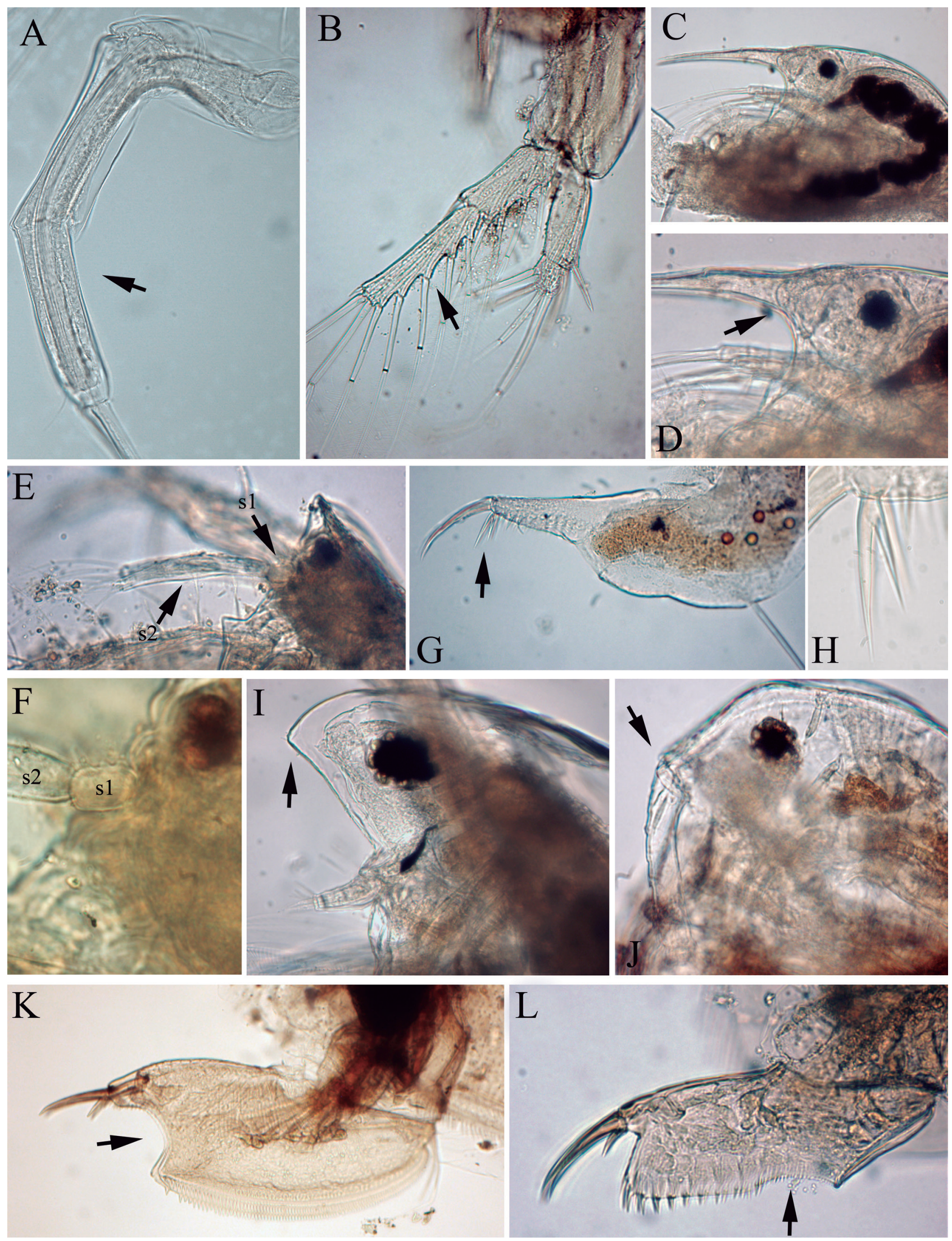

Figure 1. Morphological traits used for separation of families of Cladocera. (A) Antenna of a Holopedium Zaddach, 1855, Holopedidae, arrow showing the absence of lateral setae on the branch. (B) Antenna of a Pseudosida Herrick, 1884, Sididae, arrow showing the presence of lateral setae on the outer branch. (C) Antennule of a Bosmina Baird, 1845, Bosminidae. (D) idem, arrow showing the absence of articulation between rostrum and antennule. (E-F) Bi-segmented antennule of an Ilyocryptus Sars, 1862, llyocryptidae. (G) Postabdomen of a Moinodaphnia Herrick, 1887, Moinidae, arrow showing the position of the bifurcate marginal denticle. (H) idem, bifurcate marginal denticle. (I) Head and antennule of a Simocephalus Schoedler, 1858, Daphniidae, arrow showing the apex of head. (J) Head and antennule of a Macrothrix Baird, 1843, Macrothricidae, arrow showing the apex of head. (K) Postabdomen of a Eurycercus Baird, 1843, Eurycercidae, arrow showing the position of the anal aperture. (L) Postabdomen of an Ovalona Van Damme \& Dumont, 2008 emend. Sinev, 2015, Chydoridae, arrow showing the position of the anal aperture. 
an fauna, and this comprises the main goal of this study. Since this is the first in a series of publications that aim to provide updated information for the identification of these crustaceans, we also provide an identification key for the orders and families of Cladocera occurring in Brazil (Fig. 1).

\section{MATERIALS AND METHODS}

The identification key of the species and subspecies of Ilyocryptus was based on material collected in different regions of Brazil, which is deposited in the personal collections of the authors of this study, or in the collection of the Laboratório de Biodiversidade Aquática of the Universidade Católica de Brasília. The main morphological characters used in the identification key correspond to structures of the carapace (such as projections and setae) and of the postabdomen (Fig. 2). The observation of these structures requires careful, fine manipulation of the material, often under high magnification. All the morphological characters used in this study refer to parthenogenetic females, given that males are rarely observed in nature.

For each Ilyocryptus taxon studied, a short diagnosis is provided, containing the main morphological characters that distinguish it, based exclusively on the taxa occurring in Brazil. The elaboration of the diagnosis also used specialized literature (Elmoor-Loureiro, 1997; Kotov \& Williams, 2000; Kotov et al., 2001, 2002; Kotov \& Štifter, 2004, 2006; Kotov \& Elmoor-Loureiro, 2008). Besides, we provide the geographical range of each taxon in maps that also show the hydrographic regions of Brazil, following resolution n. 32 of the Conselho Nacional de Recursos Hídricos (National Council of Hydrological Resources).

\section{Abbreviations}

$\begin{array}{ll}\text { Al: } & \text { antenna I } \\ \text { All: } & \text { antenna II } \\ \text { am: } & \text { anal margin } \\ \text { bs: } & \text { basal spine } \\ \text { gap: } & \text { distance between proximalmost lateral seta and } \\ & \text { anal margin } \\ \text { Is: } & \text { lateral setae } \\ \text { pam: } & \text { postanal margin } \\ \text { prm: } & \text { preanal margin } \\ \text { ps: } & \text { postabdominal setae } \\ \text { rs: } & \text { rudimentary setae } \\ \text { spm: } & \text { spines of preanal margin } \\ \text { spmc: } & \text { setae on the posterior margin of carapace } \\ \text { svmc: } & \text { setae on the ventral margin of carapace } \\ \text { s: } & \text { segment }\end{array}$

\section{RESULTS AND DISCUSSION}

Currently, the Brazilian fauna of Ilyocryptidae is composed of seven taxa: Ilyocryptus sarsi, Ilyocryptus spinifer, Ilyocryptus plumosus, llyocryptus silvaeducensis paraensis, Ilyocryptus cuneatus brasiliensis, Ilyocryptus paranaensis paranaensis and Ilyocryptus paranaensis inarmatus. In the most recent and comprehensive checklist on the Brazilian cladoceran fauna (Elmoor-Loureiro, 2000), the number of species was increased from two to seven. Herein, we report that the prediction of Kotov \& Elmoor-Loureiro (2008) that I. plumosus would be found in areas further to the south of its previously known range was correct. This species was observed in only one location in the São Francisco River hydrographic basin (Fig. 3). Therefore, there is a considerable chance that future faunal inventories will report the occurrence of Ilyocryptus elegans Paggi, 1992, another species endemic to the Neotropical region, whose distribution is currently known only in the lowest portions of the Paraná River hydrographic basin, in Argentina (Kotov \& Štifter, 2006). Ghidini et al. (2017) reported the presence of Ilyocryptus cf. elegans for an Amazon lake, but the taxonomic status of this population still needs to be confirmed.

The Brazilian fauna of Ilyocryptidae can be separated into two groups: one with two species with broad distributions; and another with five species considered rare. Ilyocryptus spinifer is considered a cosmopolitan species with high ecological plasticity (Kotov \& Williams, 2000; Kotov \& Dumont, 2000), and thus its occurrence in most of Brazilian hydrographic regions was already expected (Fig. 3). Although I. sarsi also has a broad distribution, there are few records of this species in Brazil (Fig. 3) (Sousa et al., 2010; Sousa \& ElmoorLoureiro, 2013).

Regarding the taxa considered as rare, from our point of view, we must consider that the observed pattern might be the result of historical and evolutionary processes. On the other hand, it is important to highlight that most of the species of Ilyocryptidae inhabit the bottom of water bodies, in association with the sediment, even in habitats without macrophytes (Kotov \& Štifter, 2006). Conventionally referred to as a mesobenthos member, this type of ecological community is not commonly the focus of the sampling efforts in most studies on Cladocera. Consequently, this may lead to the perceived rarity of many taxa (concerning both their distribution and the number of populations/individuals), and the perception may be the result of a sampling bias. For the Neotropics, the assumption is supported by the occurrence of taxa with broad distributions, but very few records (Fig. 3).

Overall, the present study provides an analysis of the Brazilian fauna of Ilyocryptidae, in which we discuss the bases for the morphological comparisons through the diagnoses of the aforementioned taxa, as well as an updated identification key for the species and subspecies. Some of the taxa found in Brazil are still considered rare, but it is possible that this pattern is a result of the lack of sampling efforts aimed at the mesobenthos. The species richness of Ilyocryptidae in Brazil is probably still underestimated. 


\section{Identification key for the orders and families of Cladocera}

1a Six pairs of foliaceous thoracic appendages, morphologically similar

Order Ctenopoda Sars, 1865 (2)

Five or six pairs of thoracic appendages, morphologically distinct.

Order Anomopoda Sars, 1865 (3)

Antenna with one branch, without lateral setae

Holopedidae Sars, 1865 (Fig. 1A)

Antenna with two branches, external branch (exopodite) with numerous lateral setae.

Sididae Baird, 1850 (Fig. 1B)

Antennule non-movable, fused with rostrum.

Bosminidae Baird, 1845 (Fig. 1C-D)

Antennule movable, not fused with rostrum

.... 4

Antennule with two segments

.llyocryptidae Smirnov 1976 emend. Smirnov, 1992 (Fig. 1E-F)

Antennule not segmented

Moinidae Baird, 1850 (Fig. 1G-H)

Postanal part of postabdomen narrow and conical, distalmost marginal denticle generally bifurcate

Postanal part of postabdomen not conical

Internal branch (endopodite) of antenna with four segments and external branch (exopodite) with three segments ..................................................... 7

Antenna with three segments on the internal (endopodite) and external branches (exopodite) ...................................................................................... 8 Antennule inserted or articulated on the posteroventral part of head......

Daphniidae Straus, 1820 (Fig. 11)

Antennule articulated on the anteroventral part of head

Macrothricidae Norman \& Brady, 1867 (Fig. 1J)

Anal aperture positioned in the distal part of postabdomen

.Eurycercidae Kurz, 1865 sensu Dumont \& Silva-Briano, 1998 (Fig. 1K)

Anal aperture positioned in the dorsal margin of postabdomen Chydoridae Dybowski \& Grochowski, 1894 emend. Frey, 1967 (Fig. 1L)

\section{Identification key for the species and subspecies of Ilyocryptidae}

$1 a$
$1 b$
$2 a$
$2 b$
$3 a$
$3 b$
$4 a$
$4 b$
$5 a$
$5 b$
$6 a$
$6 b$

Valves with lateral projection

Valves without lateral projection

Spine on the second segment of endopodite of antenna bi-segmented......

Ilyocryptus paranaensis inarmatus

Spine on the second segment of endopodite of antenna not segmented .llyocryptus paranaensis paranaensis

Preanal margin of postabdomen with duplicated denticles (one or more)

Preanal margin of postabdomen with regular denticles.

Distalmost part of postanal margin of postabdomen with 4-5 rudimentary setae; up seven long lateral setae

..llyocryptus cuneatus brasiliensis

Distalmost part of postanal part of postabdomen with eight rudimentary setae; 8-9 long lateral setae.

Ilyocryptus silvaeducensis paraensis

Postanal part of postabdomen with 3-4 long lateral setae; a long "gap" between proximalmost lateral seta and anal margin

Postanal part of postabdomen with 5-7 lateral setae; "gap" not developed

Setae on the posterior margin of carapace with inflated base and armed with a single spine Ilyocryptus spinifer

Setae on the posterior margin of carapace with regular morphology, without spine ..llyocryptus plumosus

\section{Diagnosis of the Brazilian species and subspecies of Ilyocryptus}

\section{Ilyocryptus cuneatus brasiliensis Kotov \& Elmoor-Loureiro, 2008}

Sub-ovoid body, dorsal keel present but not developed, molting incomplete; setae on the posterior margin of valves armed with relatively long and slender setae, spines unilaterally inserted, without setulae; posteriormost setae on the valves armed with setulae. Head triangular shaped, fornices prominent, projection on the mandibular articulation present; dorsal pore high in relation dorsal line. Postabdomen relatively short, preanal part longer than postanal; 5-10 marginal denticles on the preanal part, duplicated; anal part short with 5-6 short lateral setulae; seven marginal spines on the postanal part; distalmost part of postanal part with 4-5 rudimentary lateral setae, up seven lateral setae which are slightly longer than marginal spines; basal spines on the postabdominal claw of similar length.

Comments: Ilyocryptus cuneatus brasiliensis is the only Neotropical taxon of a group composed almost exclu- sively of Palearctic species. This appears to be rare, with a range restricted to two localities in the state of São Paulo, belonging to the Paraná River Hydrographic Basin (Fig. 3A). For further information concerning the morphology of this taxon and its differentiation from other subspecies occurring in other zoogeographical zones, see Kotov \& Elmoor-Loureiro (2008).

\section{Ilyocryptus paranaensis inarmatus Kotov, Eliáz-Gutiérrez \& Gutiérrez-Aguirre, 2001}

Ovoid body, dorsal keel present but not developed, molting complete; each valve bears a horn-like projection; depression between head and rest of body well developed; setae on the posterior margin of valves with inflated base and armed with a single spine which is followed by setulae; posteriormost setae on the valves armed with setulae. Head triangular shaped, fornices prominent; first segment of antennules with developed mounds; spine on the second segment of endopodite of antenna bi-segmented. Postabdomen wide, preanal part slightly longer than postanal; marginal denticles of the preanal part with regular morphology; 7-9 marginal spines; distalmost part of the postanal part with 7-13 ru- 


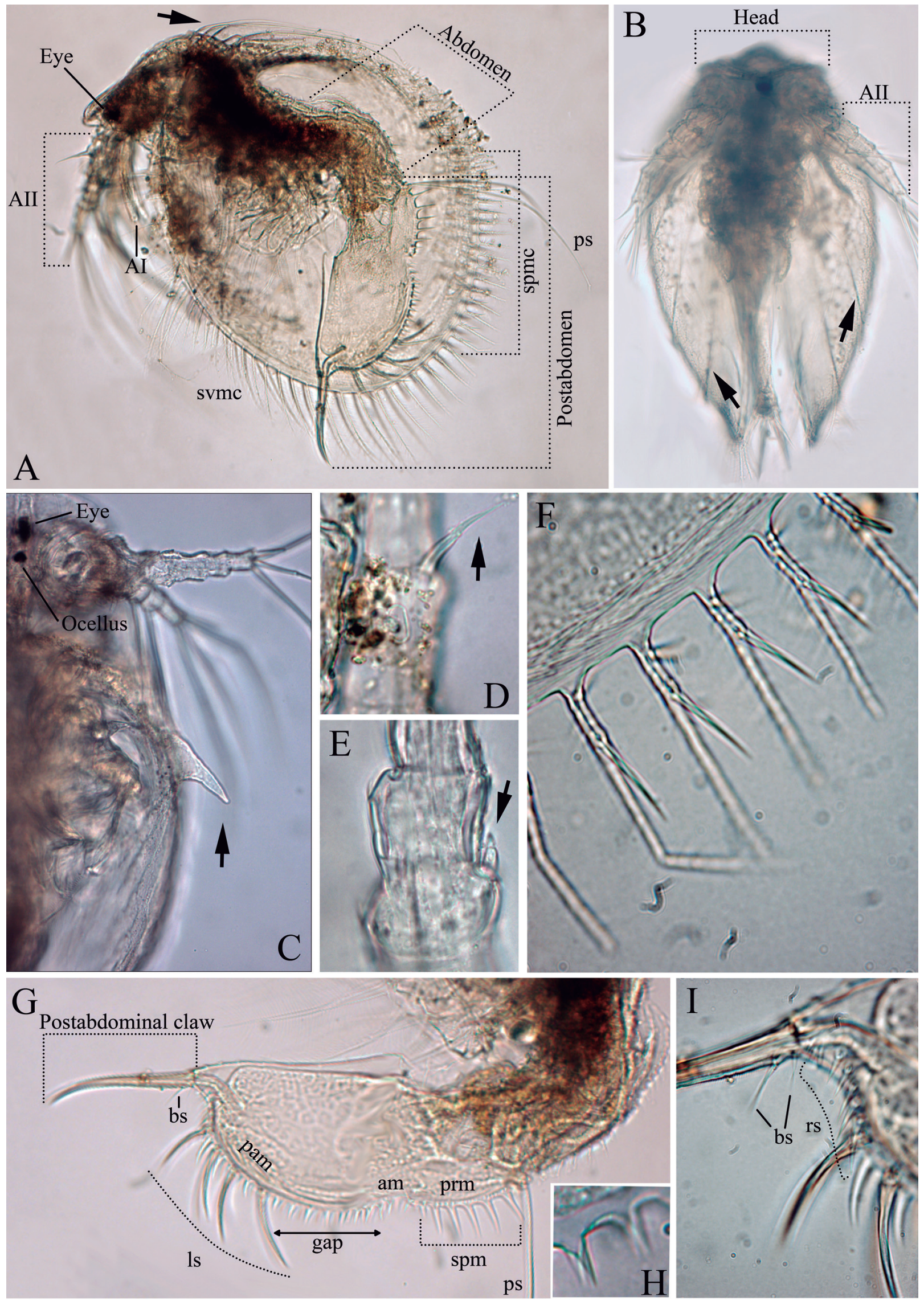

Figure 2. General features of llyocryptidae Smirnov 1976 emend. Smirnov, 1992 morphology based on the morphological traits used in the identification key. (A-B, D, F-G, I) Ilyocryptus spinifer. (C-E) Ilyocryptus paranaensis inarmatus. (H) Ilyocryptus cuneatus brasiliensis. (A) Lateral view, arrow showing the molting incomplete. (B) Ventral view, arrow showing the molting incomplete. (C) Ventral view, seta showing the lateral projection. (D) Non-segmented spine of the endopodite of antenna. (E) Segmented spines of the endopodite of antenna. (F) Setae on the posterior margin of the carapace, with inflated base and a spine. (G) Postabdomen. (H) idem, duplicate spines on the preanal marain. (I) idem, basal spines and rudimentarv setae. 
dimentary lateral setae, up six long lateral setae which are markedly longer than marginal spines; basal spines on the postabdominal claw of different length.
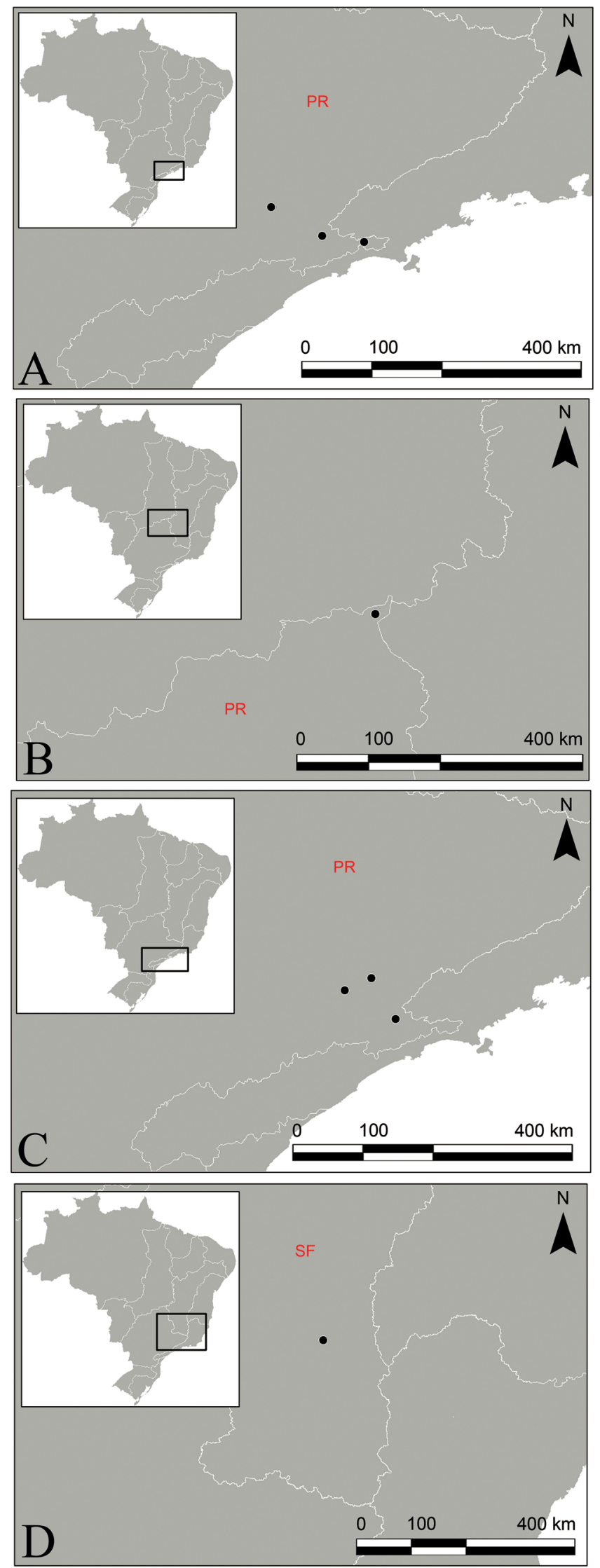

Comments: llyocryptus paranaensis inarmatus was initially described from materials obtained in different parts of Mexico. It is likely that this taxon possesses
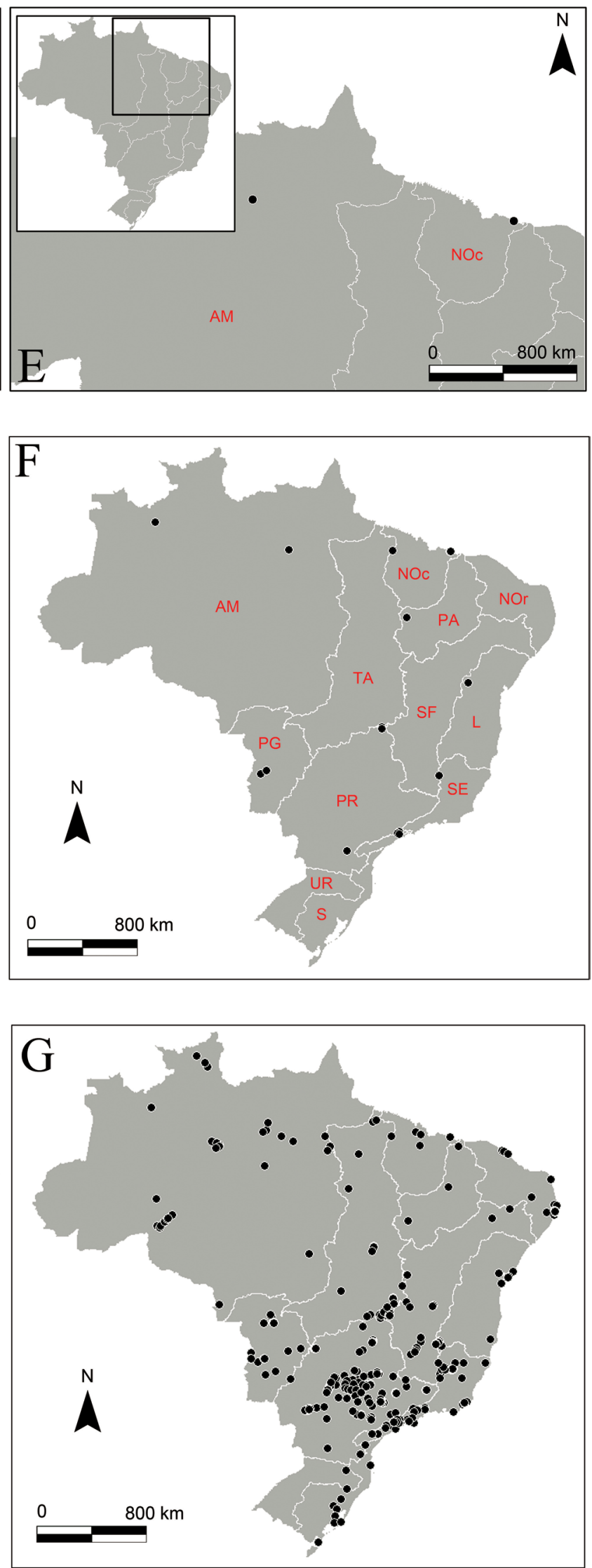

Figure 3. Geographic distribution llyocryptidae Smirnov 1976 emend. Smirnov, 1992 taxa of Brazil. (A) Ilyocryptus cuneatus brasiliensis. (B) Ilyocryptus paranaensis inarmatus. (C) Ilyocryptus paranaensis paranaensis. (D) Ilyocryptus plumosus. (E) Ilyocryptus silvaeducensis paraensis. (F) Ilyocryptus sarsi. (G) Ilyocryptus spinifer. 
a broad distribution in the Neotropics, even though there is only one known record (in central Brazil) obtained from outside its type-region (Fig. 3B). For further information regarding the morphology of this species regarding the Brazilian population, or information concerning its habitat, see Sousa \& ElmoorLoureiro (2011).

\section{Ilyocryptus paranaensis paranaensis Paggi, 1989}

Ovoid body, dorsal keel present but not developed, molting complete; each valve bears a horn-like projection; depression between head and rest of body not developed; setae on the posterior margin of valves with inflated base and armed with a single spine which is followed by setulae; posteriormost setae on the valves armed with setulae. Head triangular shaped, fornices prominent; first segment of antennules with low mounds; spine on the second segment of endopodite of the antenna not segmented. Postabdomen wide, length of preanal similar to postanal; marginal denticles of the preanal part with regular morphology; 10-14 marginal spines; distalmost part of the postanal part with 5-9 rudimentary lateral setae, up seven long lateral setae which are markedly longer than marginal spines; basal spines on the postabdominal claw of different length.

Comments: llyocryptus paranaensis paranaensis occurs from Argentina to Venezuela. In Brazil, this taxon was found in three localities in the state of São Paulo (Fig. 3C). The complete description of llyocryptus paranaensis can be found in Paggi (1989) and Kotov \& Štifter (2006).

\section{Ilyocryptus plumosus Kotov \& Štifter, 2004}

Ovoid body, dorsal keel well developed, molting incomplete; setae on the posterior margin of valves without spine but armed with setulae. Head triangular shaped, fornices prominent; spine on the second segment of endopodite of antenna shorter than mid length of the third segment. Postabdomen large, preanal part shorter than postanal; marginal denticles of preanal part with regular morphology, decreasing of length towards anal part; 17-20 marginal spines which increase in length towards distal part of postabdomen; distalmost part of postanal part with 3-6 rudimentary lateral setae, up four long lateral setae about 5-7 times longer than marginal spines; a long "gap" between proximalmost lateral seta and anal margin. basal spines on the postabdominal claw of different length.

Comments: This is the first report of llyocryptus plumosus in Brazil. The description of I. plumosus was based on materials sampled in Venezuela and Nicaragua. In Brazil, this species is rare and only known for the Serra do Cabral hills, state of Minas Gerais (Fig. 3D). The complete description of this species, including the thoracic appendages, can be found in Kotov \& Štifter (2004).

\section{llyocryptus silvaeducensis paraensis Kotov \& Elmoor-Loureiro, 2008}

Body triangular-ovoid shaped, dorsal keel developed, molting incomplete; setae on the posterior margin of valves with spines unilaterally inserted, which decrease toward distal part, setulae present. Head triangular shaped, apex slightly rounded. Postabdomen relatively short, pre and postanal part of similar length; anal margin short with 7-9 setulae inserted laterally; 3-4 denticles of preanal part duplicated; 12-14 marginal spines; distalmost part of postanal part with eight rudimentary lateral setae, 8-9 long lateral setae longer than marginal spines; basal spines on the postabdominal claw of different length.

Comments: llyocryptus silvaeducensis paraensis has an occurrence range restricted to two locations in Northern Brazil (Fig. 3E). This is the only Neotropical taxon that belongs to the silvaeducensis group. For further information regarding the morphology of this taxon and its differentiation from subspecies of other zoogeographical regions, see Kotov \& Elmoor-Loureiro (2008).

\section{Ilyocryptus sarsi Stingelin, 1913}

Ovoid body, dorsal keel present but not developed, molting incomplete; setae on the posterior margin of valves with inflated base and armed with a slender and sharp spine, setulae present. Head triangular, ovoid or semi-ovoid, fornices prominent; postabdomen relatively short, preanal and postanal part of similar length; anal margin short with 6-9 setulae inserted laterally; marginal denticles of preanal part with regular morphology, relatively long; 17-20 marginal spines, of which median ones have similar length; 5-7 lateral setae markedly longer than marginal spines; "gap" between proximalmost lateral seta and anal margin not developed; basal spines on the postabdominal claw of different length.

Comments: llyocryptus sarsi was treated in ElmoorLoureiro (1997) as Ilyocryptus sordidus Liévin, 1848, a species with Palearctic distribution. However, Kotov et al. (2001) found a significant number of differences between these two species. In spite of the low number of records (Fig. 3F), llyocryptus sarsi has a broad occurrence range in Brazil.

\section{Ilyocryptus spinifer Herrick, 1882}

Body sub-ovoid or triangular shaped, dorsal keel well developed, molting incomplete; setae on the posterior margin of valves with inflated base and armed with a long and sharp spine, setulae present; posteriormost setae on the valves armed with setulae. Head triangular shaped, fornices prominent and with a projection in the region of mandibular articulation; spine on the second segment of endopodite of antenna longer than midlength of the third segment. Postabdomen large, preanal part shorter than postanal; marginal denticles of preanal 
part with regular morphology, relatively long; 16-14 marginal spines of similar length; 3-5 long lateral setae about 4-5 times longer than marginal spines; a long "gap" between proximalmost lateral seta and anal margin; basal spines on the postabdominal claw of different length.

Comments: This is a cosmopolitan species. It is the most commonly found Ilyocryptidae taxon in Brazilian continental waters (Fig. 3G). The morphological variation exhibited by this species was described by Elmoor-Loureiro (1997), Kotov \& Williams (2000), Kotov \& Dumont (2000), and Kotov \& Štifter, 2006.

\section{ACKNOWLEDGMENTS}

This study was supported by CNPq (Conselho Nacional de Desenvolvimento Científico e Tecnológico), FAP-DF (Fundo de Apoio à Pesquisa do Distrito Federal), FNMA (Fundo Nacional do Meio Ambiente), and SISBIOTA (process: 2010/52318-6 FAPESP; 563318/2010-4 CNPq). The authors thank Dr. Maria do Desterro Mendes for help in the production of some images.

\section{REFERENCES}

Elmoor-Loureiro, L.M.A. 1997. Manual de identificação dos Cladóceros Límnicos do Brasil. Brasília, Universa. 156p.

Elmoor-Loureiro, L.M.A. 2000. Brazilian cladoceran studies: where do we stand? Nauplius, 8(1): 117-131.

Fryer, G. 1974. Evolution and adaptive radiation in the Macrothricidae (Crustacea, Cladocera): a study in comparative functional morphology and ecology. Philosophical Transactions of the Royal Society London Serie B, 269(898): 137-274.

Ghidini, A.R.; Calixto, F.S.L. \& Bandeira, M.G.S. 2017. Richness and Composition of Cladocera (Crustacea: Ctenopoda and Anomopoda) Associated with Eichhornia azurea in the Catalão Lake Complex Área, Amazonas State, Brazil. Ensaios e Ciências: Ciências Biológicas, Agrárias e da Saúde, 21(1): 8-14.

Kotov, A.A. \& Dumont, H.J. 2000. Analysis of the llyocryptus spinifer s. lat. species group (Anomopoda, Branchiopoda), with description of a new species. Hydrobiologia, 428: 85-113.
Kotov, A.A. \& Elmoor-Loureiro, L.M.A. 2008. Revision of Ilyocryptus Sars, 1862 (Cladocera: llyocryptidae) of Brazil whit description of two new subspecies. Zootaxa, 1962: 49-64.

Kotov, A.A. \& Štifter, P. 2004. Notes on the genus Ilyocryptus Sars, 1862 (Cladocera: Anomopoda: Ilyocryptidae). 1. Ilyocryptus plumosus sp. n., a primitive Neotropical member of the I. spinifer-group. Arthropoda Selecta, 13(4): 193-198.

Kotov, A.A. \& Štifter, P. 2006. Cladocera: family llyocryptidae (Branchiopoda: Cladocera:Anomopoda).In:Dumont, H.J. (Ed.). Guides to theidentification of the microinvertebrates of the Continental Waters of the world. Leiden, Kenobi Productions, Ghent \& Backhuys Publ. 172p.

Kotov, A.A. \& Williams, J.L. 2000. Hyocryptus spinifer Herrick 1882 (Anomopoda, Branchiopoda): a redescription based on North American material and designation of a neotype from Minnesota. Hydrobiologia, 428: 67-84.

Kotov, A.A.; Dumont, H.J. \& Van Damme, K. 2002. Redescription of Ilyocryptus sarsi Stingelin, 1913. Hydrobiologia, 472: 207-222.

Kotov, A.A.; Elías-Gutiérrez \& Gutiérrez-Aguirre, M. 2001. Hyocryptus paranaensis inarmatus subsp. nov., from Tabasco, Mexico (Cladocera, Anomopoda). Crustaceana, 74: 1067-1082.

Paggi, J.C. 1989. A new species of Ilyocryptus (Anomopoda: Macrothricidae) from the River Parana basin, Argentina. Hydrobiologia, 182: 239-248.

Smirnov, N.N. 1976. Macrothricidae and Moinidae of the world. Fauna SSSR. Rakoobraznie, Moscow. 237pp.

Smirnov, N.N. 1992. The Macrothricidae of the world. Amsterdam, SPB Academic Publishing.

Sousa, F.D.R. \& Elmoor-Loureiro, L.M.A. 2011. First report of Ilyocryptus paranaensis inarmatus Kotov, Elíaz-Gutiérrez \& Gutiérrez-Aguirre, 2001 (Cladocera, Anomopoda, Ilyocryptidae) in South America. Brazilian Journal of Biology, 71(4): 1025-1026.

Sousa, F.D.R. \& Elmoor-Loureiro, L.M.A. 2012. How many species of cladocerans (Crustacea, Branchiopoda) are found in Brazilian Federal District? Acta Limnologica Brasiliensia, 24(4): 351-362.

Sousa, F.D.R. \& Elmoor-Loureiro, L.M.A. 2013. Cladocerans (Crustacea: Anomopoda and (tenopoda) of the Sempre Vivas National Park, Espinhaço Range, Minas Gerais, Brazil. Check List, 9(1): 4-8.

Sousa, F.D.R.; Elmoor-Loureiro, L.M.A.; Mendonça-Galvão, L. \& Rodrigues Júnior, I. 2010. Crustacea, Cladocera, Anomopoda, Ilyocryptidae, Ilyocryptus sarsi Stingelin, 1913: A new record and geographic distribution in Brazil. Check List, 6(2): 330-331. 